\title{
A Review of the Powers and Jurisdictional Remit of the Ombudsman Institution in Botswana
}

\author{
Daniel Adetoritse Tonwe, Ph.D. \\ Department of Political Science and Public Administration, \\ University of Benin, Benin City, Nigeria. \\ Tel: 08028427001, email: datonwe@yahoo.com
}

\section{Doi:10.5901/mjss.2013.v4n13p11}

\begin{abstract}
Impartiality and independence are two key essential characteristics of the Ombudsman offices worldwide. The whole idea of jurisdictional remit is to ensure that that the Ombudsman institution is guided so that it does not stray into areas not anticipated and thus obviate unwarranted negative consequences. However, inappropriate ouster of jurisdiction may be dysfunctional for a modern institution designed to strengthen and consolidate the institutional foundations for good governance and check-mate injustice arising from maladministration. On the basis of secondary data sources, this article examines the powers and areas of ouster of jurisdiction of the Ombudsman institution in Botswana. This paper posits that jurisdictional remit potentially go beyond guiding the Botswana Ombudsman from straying into areas not anticipated to rendering even the statutory powers meaningless. This paper recommends that Botswana needs to take steps to revisit the powers and spheres of ouster of jurisdiction of the Ombudsman and make necessary statutory alignments to create a solid foundation that will ensure increased public confidence and operational effectiveness.
\end{abstract}

Keywords: Ombudsman; Review; Powers; Jurisdictional Remit; Botswana.

\section{Introduction}

Social scientists have for several decades recognized complaining as a major form of political participation (Kweit and Kweit 1981). Which ever way it is perceived, citizen complaints and redress of their grievances evidently have a critical impact on modern government. The ever increasing size, activities, and the danger of unresponsiveness of modern government, call for a balancing force to protect the individual rights and maintain the citizen's control over his government. This is basic to democratic government and the open society. All democratic constitutional systems affirm the premise of government by the people as fundamental to the democratic concept. Periodic elections afford opportunity for the expression of popular will in the legislative area; presidential elections give the electorate the same type of control over the top executive level. On grounds of ideological contestations, not all governmental systems are democratic and as such periodic elections may be non existent. In the administrative area however, with its burgeoning power and substantial impact on the individual, there arose the need for an institution with great psychological value to provide each person with a systematic method of redressing his dealings with the government bureaucracy.

One fascinating and universally accepted institution for the redress of grievances is the Ombudsman. The uniqueness of the Ombudsman institution emanates from the fact that it holds so much appeal to diverse systems of government with conflicting ideological backgrounds. In the context of the problematic character of governance, ensuring harmonious government-citizen's relations is critical. All over the world, the Ombudsman institution has been largely used to ease tensions arising from maladministration. The Ombudsman had not only always played a complementary role alongside the traditional mechanisms of legal protection of citizens, but has proved to be a useful tool for building good governance by increasing accountability in public administration.

\section{Crystallizing the ombudsman institution}

The word Ombudsman has a Swedish origin. The word ombuds in Swedish means an officer or spokesman or representative. The Dictionary of Public Administration defines ombudsman as an independent, high-level official, usually with legal training, who is authorized to handle complaints from citizens who are not satisfied with the actions or lack of actions of any administrator in government, through the process of: (1) inquiring into the matters involved, and; (2) 
making recommendations for appropriate solution (Raj, 1998; Sarker and Alam 2010). Rowat (1986) defines ombudsman as an independent and politically neutral officer of the legislature who receives and investigates complaints from the public against administrative action and who has the power to criticize and publicize but not the reverse such action. Sultana (2007) coneptualised ombudsman as an institution established under the constitution or by the legislature that receives and investigates complaints reported by individual citizens against any government and institution and recommend corrective actions. The International Bar Association (IBA) approved a resolution defining an ombudsman as an office provided for by the constitution or by an action of the legislature or parliament and headed by an independent, high-level public official who is responsible to the legislature or parliament, who receives complaints from aggrieved persons against government agencies, officials, an employer or who acts on his motion, and who has the power to investigate, recommend corrective action and issue reports (Haller, 1998; Sapers \& Zinger 2010).

In effect, Ombudsman is a novel institution of the government which is vested with the responsibility to defend and uphold the rights of the citizens in the light of how they have been treated by government officials, to investigate these complaints and, where it finds them justified, propose remedial action (Birkinshaw, 1994). When remedial action is not implemented by the concerned establishment, it can publicize the case and report on it to parliament. Basically, Ombudsmen are inquisitorial, not adversarial. Ombudsmen can examine and interview witnesses and use professional experts where appropriate. The procedure for investigations can be tailored to the circumstances of the case (British \& Irish Ombudsman Association, 2009).

From the above conceptualisation, it is evident that ombudsmen have dual roles. On one hand, they provide redress for individual grievances, while on the other hand they are concerned with the improvement of service delivery standard. In effect, an Ombudsman is not just an agent of redress, but also has a quality-control function. By investigating individual cases, Ombudsmen may highlight weaknesses in practices, rules and attitudes. Unearthing these weaknesses is of advantage to both complainants and those who have not complained. This is because the resultant improvement in the system benefits all. It is instructive to note that these two roles do not conflict and as such need not be separated (Emiola 2002). Any institution that receives and investigates complaints is only doing half its job if its casework experience is not used to provide comprehensive feedback to the organization investigated. Such feedback could help improve the way internal complaints are dealt with. This may reduce the number of complaints that would get to the Ombudsman. Feedback could also lead to improvements when investigations reveal systemic problems or failures.

While the Ombudsman is no doubt a novel institution, it must be stated that, it is by no means a superadministrator, vested with the power to overturn every wrong action and to provide correct answers to all the difficult questions that confront modern government (lluyomade \& Eka 1980).

\section{Origin, growth and structure of the ombudsman institution}

Historically, the ombudsman arose by chance rather than design when in 1713 King Charles XII of Sweden (1682-1718) decreed that there should be a supreme representative of the king-later called Chancellor of Justice to supervise government officials (Rowat, 1986; Wade, 1967). In the nineteenth century, there was remarkable growth of parliamentary government, and there arose a genuine apprehension that the chancellor's appointment by and dependence on the King did not create the necessary congenial atmosphere to function effectively as a public watchdog over the activities of the government (Reif, 2004). The response to this fear was the creation of the post of JustitieOmbudsman (Ombudsman for Justice) to replace the earlier prototype when the new constitution of the country was adopted in 1809. Under 1809 constitution, the Swedish Parliament (Riksdag) took the power to appoint an Ombudsman from the King with far-reaching powers to ensure compliance with the law of the land by the administrative organs of the state.

The growth of this novel institution has been phenomenal. It spread first to nearby Scandinavian countries with its adoption in Finland (1919), Denmark (1955) and Norway (1962). Common law countries were late comers to the system. This may be attributed to a number of factors such as their prejudice against the French system of administrative adjudication and the anonymity of the British public service. But they found no strong inhibition against this Scandinavian innovation, since it could be adapted to suit their system. In the Commonwealth, New Zealand led the way in 1962 in establishing the office and in 1967 Britain followed suit. France, in spite of its effective system of administrative courts, found it desirable to embrace the ombudsman institution in 1973. In several other European countries, the institution of Ombudsman has been created with different nomenclatures. The Ombudsman is called Médiateur in Belgium, France and Luxembourg, Provedor de Justiça in Portugal, Chancellor of Justice in Finland, Parliamentary Commissioner in Hungary, People's Advocate in Romania, etc. Interestingly, a supranational body like the European Union created the 
institution under the Maastricht Treaty and appointed the first European Ombudsman in 1995 (Reif, 2004). The first African country to adopt the system is Tanzania which, under its interim constitution of 1965, provided for the basic framework of the institution. It was called the Permanent Commission of Enquiry (PCE) (Emiola, 2001).

Since Tanzania blazed the trail in establishing the Ombudsman institution in Africa in 1965, several African countries have introduced and maintained Ombudsmen institutions with varying degrees of success (Fombad 2001). The Ombudsman in Africa has been adopted by regimes that have little resemblance to the liberal democracies with which the institution, in its classic form, is usually associated. Thus, the Tanzania PCE, like Zambia's Commission for Investigation (CFI), operated under a one-party system, while Nigeria's Public Complaints Commission (PCC) was conceived and operated within a military dictatorship for the period it lasted, and in Mauritania and Zimbabwe, similar institutions have existed under semi-liberal democracies. In the former apartheid regime in South Africa, Ombudsmen institutions were introduced with great vigour. In many respects, the introduction of this institution within the essentially closed and authoritarian African regimes of the past was a contradiction in terms. Judged from the perspective of its classic model, some analysts have considered their performances on the continent as disappointing (Hatchard 1996). In the case of Tanzania; it is arguable that the PCE was conceived principally to make the one-party system more palatable rather than to check maladministration. In the same vain, Swaziland's short-lived romance with the Ombudsman concept in 1983 was little more than an attempt to counter and neutralise pressure for a multi-party system. Under the apartheid system, South Africa sought to use the institution to mask the inherently anti-democratic and inhumane nature of the regime (Fombad 2001). Nevertheless, whatever the reasons for adopting the Ombudsman institution, and even where they have not worked well as envisaged in classic model, most studies of their operation on the continent show clearly that their very existence made for better conditions than those that prevailed in their absence (Hatchard 1996). The Ombudsman institution is now widely accepted as one of the key components of the democratic transition in Africa. The first generation of Ombudsman institutions is a clear reflection of a more open and liberal atmosphere on the continent.

Basically, there are three types of Ombudsman. On the basis of mode of appointment, there are three forms. The first is the ombudsman who is appointed by parliament and responsible to it. The second is the Ombudsman appointed and removable by the executive. This kind of ombudsman spans both the democratic western world and Eastern Europe. The third is the type of ombudsman who is appointed jointly by the executive and the legislature and controlled by both. The mode of appointment, control and removal is not necessarily inconsistent with the effective discharge of the functions of an ombudsman.

From the perspective of composition, there is the singular and collegiate system. There is the view that a collegial system whereby more than one commissioner takes charge of an investigative work is generally preferable. Tanzania started with a three-member permanent commission of enquiry but the number of members was later increased to five. Some scholars prefer the collegiate system as it provides room for consultation, thereby avoiding arbitrariness that results from a one-man show, and also addressing the problem of over-working a single person (Hogan 1971). Some countries, such as Sweden have changed to the collegiate system. However, in Britain, a parliamentary commissioner for administration for the various services is still in vogue.

In terms of the powers/functions assigned to the Ombudsman, there are two distinct types. The first, which is the classic model, is based on the Swedish and Finnish Ombudsmen. It grants enormous powers and a very broad mandate to the Ombudsman. Most importantly, the conduct of the judiciary is included in the institutions jurisdiction. The second is the Danish model which concentrates on the control of administrative activities of the executive branch of government. There is also what may be called a mixed model. For example, the Slovenian model is a combination of both. In addition to powers over state bodies, the Slovenian Ombudsman is vested with some limited jurisdiction over judicial procedures. The Slovenian model is also both reactive and proactive; as the ombudsman can investigate the matter of concern at his own initiative.

\section{Theoretical framework}

This work adopts the utilitarian theory in explaining the role of the Ombudsman in modern society. The existence and application law is the hallmark of every civilized society. Order in society largely presupposes equality before the law. Law theoretical presupposes equality not subjection. Law is the peaceful means of settling conflicting interests of persons who are treated as being on an equal basis or footing, however much they may be unequal in fact. In the ideal situation or the ultimate perfect society, individual interests will not conflict for there will be unity of purpose. When the perfect society is achieved, there will be no need for law. So to the Marxist, law rests on socialist property, annihilation of exploitation and social inequality, distribution in proportion to labour, a guarantee to each member of the society of the 
complete and manifold development of all his creative forces and true human freedom and personal independence (Dias 1976).

The notion of law represents the accommodation and sustenance of two basic different needs and these are the need for uniformity and the need for flexibility. Uniformity is needed partly to provide certainty and predictability. Where rules of law are fixed and generalized, the citizen can plan his activities with a measure of certainty and predict the legal consequences of his behaviour. It also helps to substitute fixed rule for the arbitrary fiat of Judges; for a government of laws is preferable to one of men; not simply by virtue of being less uncertain; but by reason of releasing the citizen from the mercy of other human beings (Fitzgenald 1966).

The need for flexibility is informed by the fact that society is not static but dynamic. It is known that existing rules scarcely takes care of exceptional cases. As legal realism had shown, no rule can provide for every possible case. Some measure of discretion, therefore, is provided for. Flexibility, therefore, is necessary to enable the law to adapt itself to social change. As society changes so does its needs. Therefore, a serviceable legal system must be able in its development to take account of new social, political and economic requirements. Given an unalterable system of law, the necessary changes can only be brought about by violence and upheaval; but law that is capable of adaption, whether by legislation or judicial development allows for peaceful change.

The essence of law is to guide against injustice. Injustice is the charge leveled against men, acts or laws that treat one or more persons more harshly or more favourably than others in the same situation. Selective application of law is injustice and an unjust law is no law. In effect, justice is the goal of law. Justice operates at two levels. These are distributive and corrective. Distributive justice works to ensure a fair division of social amenities/benefits and burden among the members of a community. It serves to secure a balance or equilibrium among the members of society. Distributive justice is operationalized through enactments of constitutions, codes and laws.

Corrective justice complements distributive justice. It ensures that the established societal equilibrium is sustained. When the balance in the society is upset, corrective justice comes into play to correct the disequilibrium by providing compensation or remedy of some sort. In effect, distributive justice helps to secure fair or equal distribution, while corrective justice helps to redress the inbalance of benefits and burdens in a society (Fitzgenald 1966). The function of courts and ombudsman is chiefly that of applying justice in its corrective sense. There is no gainsaying that the establishment and function of the ombudsman institution is predicated on the utilitarian principle. This is supported by the fact that the ombudsman focuses on the individual and its function is chiefly that of applying justice in its corrective sense. This account for why a person's interest is a precondition for investigating any complaint by the ombudsman. The powers and jurisdictional remit mix of the Ombudsman must therefore be such as to ensure that the office function to archive utilitarian objective of correcting the disequilibrium occasioned by injustice arising from maladministration.

\section{The ombudsman institution in Botswana}

The call for the adoption of an Ombudsman institution in Botswana was mooted more than twenty years before its establishment. The call dates back to the early 1970s. Though the need for an Ombudsman was highlighted in 1974 in the manifesto of the ruling Botswana Democratic Party, the proposal did not see the light of day after its electoral. In 1982, further impetus was given to the idea, when the Presidential Commission on Economic Opportunities recommended the establishment of a 'Public Commissioner' to address complaints of inefficiency, delays and malpractice in the administration. As a follow-up to several studies undertaken by the government, an International Seminar was held in Botswana in 1993 on The feasibility of the Ombudsman institution in Botswana (Fombad 2001). The focus of several participants at this forum on the British Ombudsman model, the Parliamentary Commissioner for Administration (PCA) was a tremendous boast to the emergence of the Ombudsman institution in Botswana. The promulgation of the Ombudsman Act was precipitated by the series of corruption and mismanagement scandals in the early 1990s. The government gave priority to checkmating corruption by pushing through the far-reaching Corruption and Economic Crime Act, 1994, under which the Directorate on Corruption and Economic Crime (DCEC), an anti-corruption agency, was established. It was evidently reasoned that the corruption problem had to be tackled first as an Ombudsman institution cannot achieve much in a situation where the civil service is very corrupt. In 1995, the Botswana Ombudsman Act establishing the first Ombudsman institution in the country was eventually promulgated. In terms of content and scope, the Botswana Ombudsman is akin to the Parliamentary Commissioner for Administration in Britain. The Botswana Ombudsman Act became operational on $1^{\text {st }}$ December, 1997. 


\section{Powers and the areas of ouster of jurisdiction of the ombudsman in Botswana}

The Botswana Ombudsman Act (1997) provides for the powers of the Ombudsman institution. Section 3(1) in this regard states that; subject to the provisions of this section, the Ombudsman may investigate any action taken by or on behalf of a government department or other authority to which this Act applies, being action taken in the exercise of administrative functions of that department or authority, in any case where:

(a) a complaint is made to the Ombudsman by a member of the public who claims to have sustained injustice in consequences of maladministration in connection with the action so taken;

(b) the complaint is referred to the Ombudsman, with the consent of the person who made it, by the President, a Minister or any member of the National Assembly with a request to conduct an investigation thereon; and

(c) in any other circumstances in which the Ombudsman on his own motion considers it necessary to investigate the action on the ground that some person has or may have sustained such injustice.

Section 3(4) also states that in determining whether to initiate, continue or discontinue an investigation under this Act, the Ombudsman shall, subject to the preceding provisions of this section, act in accordance with his own discretion; and any question whether a complaint is duly made under this Act shall be determined by the Ombudsman.

With regards to those who may not be able to appear physically, section 3(8) provides that where any person by whom a complaint might have been made under this Act has died or is for any reason unable to act for himself, the complaint may be made by his personal representatives or by a member of his family or other individual suitable to represent him.

There are several restrictions placed on the Ombudsman's investigative jurisdiction in Botswana. Section 4 of the Botswana Ombudsman Act contains matters not to be investigated by the Ombudsman. This section clearly states that the Ombudsman shall not investigate any action or actions taken in respect to any of the following;

(a) matters certified by the President or a Minister to affect relations or dealings between the Government of Botswana and any other Government or any international organisation;

(b) action taken for the purposes of protecting the security of the State or of investigating crime, including action taken with respect to passports for either of those purposes;

(c) the commencement or conduct of civil or criminal proceedings in any court;

(d) action taken in respect of appointments to offices or other employment in the service of the Government of Botswana or appointments made by or with the approval of the President or any Minister, and action taken in relation to any person as the holder or former holder of such office, employment or appointment;

(e) action taken with respect to orders or directions to the Botswana Police Force or Botswana Defence Force or member thereof;

(f) the grant of honours, awards or privileges within the gift of the President;

(g) action taken in matters relating to contractual or other commercial dealings with members of the public other than action by an authority mentioned in section 3(6);

(h) action taken in any country outside Botswana by or on behalf of any officer representing the Government of Botswana or any officer of that Government;

(i) any action which by virtue of any provision of this Act or any other enactment may be enquired into by a court of law.

\section{Powers and restrictions of the ombudsman institution in Botswana: A critique}

In all Ombudsman and Ombudsman-like institutions throughout the world, exclusions are a common feature. The whole idea of jurisdictional remit is to ensure that an institution is guided so that it does not stray into areas not anticipated and thus obviate unwarranted negative consequences. However, some of these exclusions may be dysfunctional for a modern institution designed to strengthen and consolidate the institutional foundations for good governance and checkmate injustice arising from maladministration. A critique of the key restrictions placed on the Ombudsman's investigative jurisdiction Botswana is germane at this point.

A critical examination of the powers and restrictions of the Ombudsman institution in Botswana is revealing. The extent of powers conferred on the Botswana Ombudsman under Section 3(1) of Ombudsman Act in terms of sphere of authority is very limited. Under Section 3(7) of the Act, the Judicial Service Commission and the Public Service Commission are not to be regarded as departments of Government that can be investigated by the Botswana Ombudsman. In contrast, in Nigeria under Section 5 of the Public Complaints Commission Act the Public Complaints 
Commission (PCC) is empowered to investigate any department or ministry of the Federal or any State government as well as any department of any local government authority (howsoever designated) set up in any state in the federation; any statutory corporation or public institution set up by any government in Nigeria; any company incorporated under or pursuant to the Companies Act 1968 whether owned by any government aforesaid or by private individuals in Nigeria.

In Botswana the police and the armed forces are excluded from the jurisdiction of the Ombudsman. The interpretation given to the role of the Ombudsman in Botswana in relation to the police and the armed forces has been that of blanket exclusion. There is obviously no problem if the internal complaints-handling system within the two forces is used to handle complaints by its members. The problem emerges where a civilian sustains injustice as a direct consequence of maladministration within these forces. This cannot be investigated by the Ombudsman despite the fact that the police and defence forces in Africa are often associated with the worst human rights abuses. Even though many Africa countries have transformed into democracy of some sort, brutality and uncivilized attitude by the police and defence forces are still very rampant. As is the case in Nigeria, the Zambian and Tanzanian Ombudsman have always had jurisdiction over the police and defence forces and there is no evidence that this has posed any threat to national security (Fombad 2001). The need to consolidate democracy and good governance in Africa negates any justification for such exclusion. However, where security concerns are crucial to the matter on hand, the Ombudsman, whose proceedings are confidential, should be allowed to appreciate the risk posed and decide whether or not to initiate or continue investigation.

Section 4(c) of the Botswana Ombudsman Act excludes action taken with respect to the commencement or conduct of civil or criminal proceedings in any court. The Botswana Ombudsman Act complicates this matter, vide section 4(i) as it excludes complaints that may cause any action which by virtue of any provision of the Act or any other enactment to be enquired into by a court of law. Basically, virtually all cases that may result in a person sustaining an injustice as a result of maladministration are also actions that may be inquired into by a court of law. This provision is superfluous if strictly interpreted. Consequently, the discretion conferred on the Ombudsman under section 3(3) to investigate matters with respect to which the aggrieved person has or had some alternative judicial or quasi-judicial right or remedy is also otiose. This interpretation of section 4(i) is interpreted strictly, it is means that the Botswana legislature has inadvertently created a redundant institution since potentially all matters may be inquired into by the courts. It would be ridiculous to contemplate that this is the position.

Also of grave concern is section 4(d) which excludes action taken in respect of appointments to offices or other employment in the service of the Government of Botswana or appointments made by or with the approval of the President or any Minister, and action taken in relation to any person as the holder or former holder of such office, employment or appointment. The argument is that, there is civil service commission that handles these matters. But the question is what happens when staff suffers injustice arising from maladministration arising from actions taken by the commission? This issue has been agitating the minds of many since the Ombudsman Act was passed in 1995. The gravity of the problems that have resulted from this is reflected by the Ombudsman in his first annual report thus:

\begin{abstract}
I have felt a keen sense of helplessness and frustration in not being able to investigate complaints of maladministration relating to public service personnel matters... The ratio of complaints emanating from the public service concerning employment and appointments as compared with others with which the jurisdiction is far too disproportionate. Since, however, these fall outside the Ombudsman's jurisdictional remit, they must necessarily be turned away much to the chagrin of those concerned (Ombudsman Report, 1998, p.10).
\end{abstract}

Section 2, subsections 1-6 of the Botswana Ombudsman Act made fairly elaborate provisions for the appointment of the Ombudsman to ensure that the person appointed to the office is able to carry out the duties of the office in an impartial and independent manner. This is commendable. However, the Botswana Ombudsman Act did not make provision for staff independent of the civil service structure that will carry out the day to day work of the Ombudsman institution. The Ombudsman in Botswana is serviced by staff from the core civil service and as such the office is not independent from Government. This has not augured well for the Ombudsman in Botswana. This position has been reiterated by the Ombudsman a number of times. In one report the Ombudsman noted thus:

In my first Annual Report I made the point that the Ombudsman Act must be amended to make the Office independent from Government. This assertion I repeat. This Office needs to be established outside of the Public Service to make it independent of any other Government Ministry. Apart from all else, this is international practice. It is important that the office be seen by the public and particularly all government departments as not being in competition with them. Neither the ombudsman nor any member of the staff should be in competition for a higher post within the government promotional hierarchy. There is indeed in my respectful submission, a manifest conflict of interest where either the 
ombudsman or an investigator investigates an officer or department when he or she may aspire for a higher position in that department. Indeed an investigation officer is put in an invidious position if they are expected to investigate the Directorate of Public Service Management, make adverse findings about the department and still expect the same department to objectively assess their prospects for promotion (Ombudsman Report, 2000, p. 14).

Section 14(g) of the Botswana Ombudsman Act excludes matters relating to contractual or other commercial dealings between the government and members of the public. This is strange and unprogressive. The privatisation and commercialisation of certain public services will no doubt adversely affect the public's participation in the efficient management of these services; some of which are crucial to national development. The need to be accountable to the public in the provision of public services is crucial and as such the Ombudsman must be empowered to intervene and investigate complaints of malpractice, whether a public service is delivered privately or the public sector firms in conjunction with private firms deliver such public services.

\section{Conclusion}

Arising from the existence of the exclusion provisions, the exact investigative jurisdiction of the Ombudsman is sometimes speculative. While all Ombudsman institutions have jurisdictional remits, the Botswana Ombudsman obviously presents distortions in terms of powers-exclusions mix. The Botswana Ombudsman Act does compare favourably with Nigeria and even with the Ombudsman schemes operating in its neighbouring states. The Namibia Ombudsman Act empowers the Ombudsman to investigate matters relating to over-utilization of natural resources and enjoys jurisdiction over private persons and enterprises where there are alleged human rights violations. In Zimbabwe, the Ombudsman Amendment Act 1997 has expounded the investigative jurisdiction of the Ombudsman to include actions by the defence and police forces and he also has the power to examine any legislation or proposed legislation, and to express an opinion as to whether or not it contravenes the declaration of rights in the constitution. The creation of the office of the Inspector-General of Government in 1986 also enhanced powers of the scheme in Uganda. To consolidate the Ombudsman institution in Botswana to perform its utilitarian function of corrective justice, it is expedient to expand its jurisdiction to include the investigation of any action or case of administrative malpractice in all ministries, departments, public and private establishment as well as local, national and foreign organization unless there is a cogent cause for excluding it.

\section{References}

Adamolekun, L. and Osunkunle, E.L. (1982). Nigeria's Ombudsman System, Ibadan: Heinemann.

Akanle, O. (1978). Self-restraint or Abdication? A Note on the Investigatory Powers the Nigerian Public Complaints Commission (Ombudsman). Ibadan: Alliance Press.

Birkinshaw, P. (1994). Grievances, Remedies and the State. London: Sweet and Maxwell.

Botswana Ombudsman Act (1997). Gaborone, Government Printer.

British \& Irish Ombudsman Association (BIOA) (2009), Guide to Principles of Good Governance, availablehttp://www.bioa.org.uk/docs.

Dias R. W.: Jurisprudence (4th Ed.) (1976). London: Butterworth.

Emiola A. (2001), Administrative Remedies, Ogbomosho: Emiola Publishers.

Federal Republic of Nigeria, Public Complaints Commission Act 1975. Lagos: Federal Government Printers.

Fitzgerald P. J. (1966), Salmon on Jurisprudence, London: Sweet \& Maxwell.

Fombad Charles Manga (2001). The Enhancement of Good Governance in Botswana: a Critical Assessment of the Ombudsman Act, 1995, Journal of Southern African Studies, 27(1), 57-76.

Haller W. (2010). The Place of the Ombudsman in the World Community, Fourth International Ombudsman Conference Papers, Canberra, Canadian Federal Corrections 15(5), 15-24.

Hatchard J. (1996). The Ombudsman in Africa Revisited, International and Comparative Law Quarterly, (40), 938-950.

Hogan, J. (1971). What Happened to Ghana's Ombudsman? Transition Magazine (40), 28.

lluyomade and Eka (1980). Cases and Materials on Administrative Law, lle-lfe: University of Ife Press.

Kweit, M. G., and Kweit R.W. (1981). Implementing Citizen Participation in a Bureaucratic Society. New York: Praeger.

Ombudsman Annual Report (1997/1998). Office of the Ombudsman, Gaborone, Government Printer.

Ombudsman Annual Report (1999/2000). Office of the Ombudsman, Gaborone, Government Printer.

Ombudsman Annual Report (2005/2006). Office of the Ombudsman, Gaborone, Government Printer.

Raj, G. (1998). Dictionary of Public Administration. Mumbai: Himalya Publishing House.

Reif, L. (2004). The Ombudsman, Good Governance, and the International Human Rights System. Leiden: Koninklijke Brill.

Rowat, D. C. (1986). The Ombudsman, Citizen's Defender. London: George Allen and Unwin.

Sapers H. and Zinger I. (2010). The Ombudsman as a Monitor of Human Rights in Canadian Federal Corrections, Available at: 
http://digitalcommons.pace.edu/plr/vol30/iss5/9

Sarker M. \& Alam B. (2010). Ombudsman for Good Governance: Bangladesh Perspective, Journal of Management and Social Sciences, 6(1), 13-23

Sultana, R. (2007). The ombudsman question. Lucknow: Universal Press.

Wade, H.W.R. (1967), Administrative Law, Oxford: Clarendon Press. 